\title{
Environmental impact of municipal dumpsite leachate on ground- water quality in Jawaharnagar, Rangareddy, Telangana, India
}

\author{
B. Soujanya Kamble ${ }^{1}$ (1) $\cdot$ Praveen Raj Saxena $^{2}$
}

Received: 26 April 2016/Accepted: 26 September 2016/Published online: 17 October 2016

(C) The Author(s) 2016. This article is published with open access at Springerlink.com

\begin{abstract}
The aim of the present work was to study the impact of dumpsite leachate on ground-water quality of Jawaharnagar village. Leachate and ground-water samples were investigated for various physico-chemical parameters viz., $\mathrm{pH}$, total dissolved solids (TDS), total hardness (TH), calcium $\left(\mathrm{Ca}^{2+}\right)$, magnesium $\left(\mathrm{Mg}^{2+}\right)$, sodium $\left(\mathrm{Na}^{+}\right)$, potassium $\left(\mathrm{K}^{+}\right)$, chloride $\left(\mathrm{Cl}^{-}\right)$, carbonates $\left(\mathrm{CO}_{3}{ }^{2-}\right)$, bicarbonates $\left(\mathrm{HCO}_{3}{ }^{-}\right)$, nitrates $\left(\mathrm{NO}_{3}{ }^{-}\right)$, and sulphates $\left(\mathrm{SO}_{4}{ }^{2-}\right)$ during dry and wet seasons in 2015 and were reported. The groundwater was hard to very hard in nature, and the concentrations of total dissolved solids, chlorides, and nitrates were found to be exceeding the permissible levels of WHO drinking water quality standards. Piper plots revealed that the dominant hydrochemical facies of the groundwater were of calcium chloride $\left(\mathrm{CaCl}_{2}\right)$ type and alkaline earths $\left(\mathrm{Ca}^{2+}\right.$ and $\left.\mathrm{Mg}^{2+}\right)$ exceed the alkali $\left(\mathrm{Na}^{+}\right.$ and $\left.\mathrm{SO}_{4}{ }^{2-}\right)$, while the strong acids $\left(\mathrm{Cl}^{-}\right.$and $\left.\mathrm{SO}_{4}{ }^{2-}\right)$ exceed the weak acids $\left(\mathrm{CO}_{3}{ }^{2-}\right.$ and $\left.\mathrm{HCO}_{3}{ }^{-}\right)$. According to USSL diagram, all the ground-water samples belong to high salinity and low-sodium type (C3S1). Overall, the groundwater samples collected around the dumpsite were found to be polluted and are unfit for human consumption but can be used for irrigation purpose with heavy drainage and irrigation patterns to control the salinity.
\end{abstract}

B. Soujanya Kamble

bsk.029@gmail.com

Praveen Raj Saxena

saxenapr@yahoo.co.in

1 Department of Environmental Science, University College of Sciences, Osmania University, Hyderabad, India

2 Department of Applied Geochemistry, University College of Sciences, Osmania University, Hyderabad, India
Keywords Groundwater · Hydrochemical analysis . Piper · Irrigation · Jawaharnagar dumpsite · Rangareddy

\section{Introduction}

Groundwater which is in aquifers beneath the earth surface is considered the most important natural resource to mankind. It is the primary source for human consumption, agriculture, and industrial purposes. In the past few decades, due to population growth, rapid urbanization, and industrialization, ground-water quantity and quality has been deteriorated especially in the developing countries, such as India. As the groundwater is an important part of the hydrological cycle, it is more prone to various sources of contamination according to Soujanya (2016). In general, the quality of groundwater varies with the location, geology, type, and quantity of dissolved ions present in it. According to Fatta et al. (1999), landfills have been identified as one of the major threats of ground-water resources. Most importantly, the groundwater located near the landfills or dumpsites is highly polluted due to the leachate produced from it. The toxic leachate rich in organic and inorganic constituents negatively influence the parametric composition of the groundwater making it unsuitable for the human sustenance. Several scientific studies were conducted worldwide to study the impact of leachate on ground-water chemistry (Longe and Balogun 2010; Vasanthi et al. 2008; Sabahi et al. 2009; Jhamnani and Singh 2009). In India, as the groundwater is the main source for drinking and irrigation, regular monitoring of the wells is required to check for various anthropogenic sequences for wellbeing and sustainability. Therefore, in the present study, physico-chemical characteristics of groundwater (dry and wet seasons) located around the municipal open 
dumpsite of Jawaharnagar village were analyzed for drinking water suitability as per WHO (2011) and various irrigation water quality determining factors, such as sodium adsorption ratio (SAR), sodium percentage $(\mathrm{Na} \%)$, permeability index (PI), soluble sodium percentage (SSP), and Kelley's ratio (KR) (Fig. 1).

\section{Materials and methods}

\section{Study location}

Hyderabad is the capital city of Telangana and Andhra Pradesh and is the sixth largest city in India. Currently, 5000 metric tons (MT) of municipal solid waste are generated in the city. This waste is collected by the waste collectors with the help of tricycle cart and dumped into the three major collection points in Hyderabad city which are located in Yousufguda, Imlibun, and Lower Tank bund. Waste from all the three collection points eventually gets collected and dumped into the Municipal Dumpsite of Jawaharnagar village without a proper segregation and recycling process. The percentage composition of the municipal solid waste generated in Hyderabad city according to Gowtham Raj et al. (2015) is shown in Fig. 2.

Municipal dump site is situated in Jawaharnagar Village, Shameerpet Mandal, Rangareddy District of Telangana. It is located just outside the limits of GHMC (Greater Hyderabad Municipal Corporation) and inside the HMDA (New limits of Hyderabad). The site is $35 \mathrm{~km}$ from Hyderabad city and $105 \mathrm{~km}$ away from the state highway connecting Hyderabad and Nagpur in west direction from

Characterization of Dumpsite Leachate

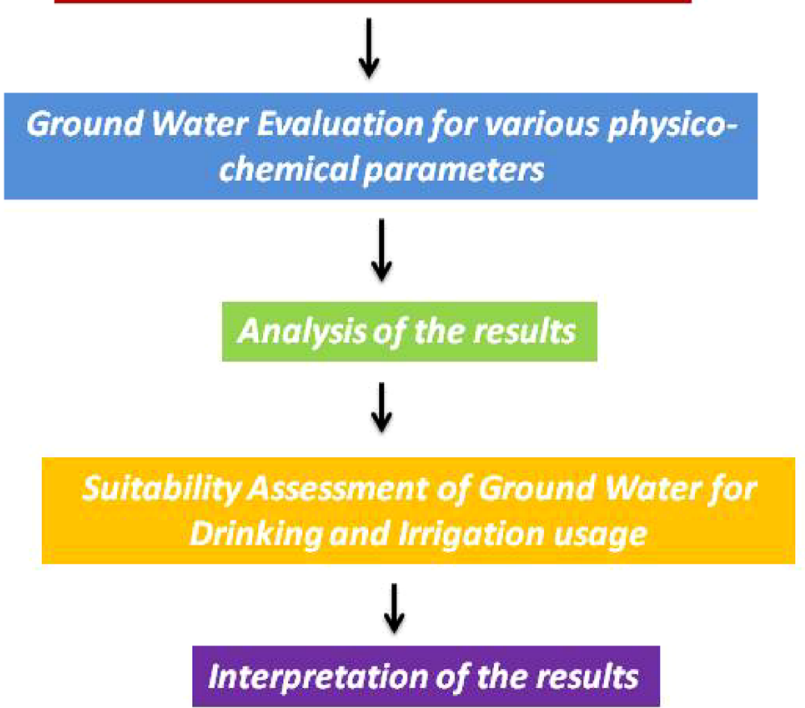

Fig. 1 Conception framework of the study

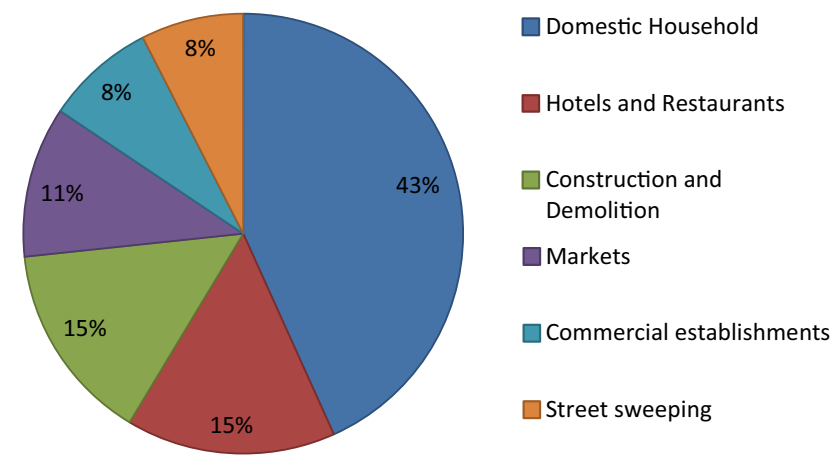

Fig. 2 Percentage composition of municipal solid waste in Hyderabad (after Gowtham Raj et al. 2015)

boundary of project site. It is an open dumpsite which was established in the year 2002. The total area of Jawaharnagar village dumpsite is 350 dekar (da) from which the area occupied by the waste at present is $182 \mathrm{da}$. It is located between $7030^{\prime} 01^{\prime \prime} \mathrm{N}$ to $17032^{\prime} 03^{\prime \prime} \mathrm{N}$ latitude and $78034^{\prime} 13^{\prime \prime} \mathrm{E}$ to $78037^{\prime} 47^{\prime \prime} \mathrm{E}$ longitude (Fig. 3). At Jawaharnagar village dumpsite, ground-water table is located at $120 \mathrm{~cm}$ below ground level. The annual mean temperature is $26{ }^{\circ} \mathrm{C}$. Summers (March-June) are hot with maximum temperatures of $40{ }^{\circ} \mathrm{C}$. Winter (December-January) has temperatures varying from 14.7 to $28.6^{\circ} \mathrm{C}$. Heavy rain from the south-west summer monsoon falls between June and September, supplying Rangareddy with most of its annual rainfall of $812.5 \mathrm{~mm}$ (32 in). Monthly rainfall distribution of the sampling year (2015) in Rangareddy district is presented in Fig. 4.

\section{Sample collection}

One leachate sample (from leachate pond) and 15 groundwater samples were collected during dry and wet period (2015) around the dumpsite as per availability. Sampling was done in $1 \mathrm{~L}$ pre-cleaned high-density polyethylene bottles (HDPE) with dilute $\mathrm{HNO}_{3}$ and was stored in the laboratory at $4{ }^{\circ} \mathrm{C}$ for 2 days until analyzes. Geographic locations of the sampling points were collected with the help of TRIMBLE GPS. The leachate and ground-water samples were analyzed for 12 parameters viz., $\mathrm{pH}$, total dissolves solids (TDS), total hardness (TH), calcium (Ca), magnesium $(\mathrm{Mg})$, sodium $(\mathrm{Na})$, potassium $(\mathrm{K})$, chlorides $(\mathrm{Cl})$, carbonates $\left(\mathrm{CO}_{3}\right)$, bicarbonates $\left(\mathrm{HCO}_{3}\right)$, nitrates $\left(\mathrm{NO}_{3}\right)$, and sulphates $\left(\mathrm{SO}_{4}\right)$ using the standard procedures recommended by APHA standards (2005).

The $\mathrm{pH}$ was measured with digital $\mathrm{pH}$ meter (HANNA Inst. Italy) and conductivity with conductivity meter. Total dissolved solids (TDS) were calculated from Electrical Conductivity (EC) using an empirical equation. Total alkalinity, total hardness, calcium, magnesium, and chlorides were estimated by titrimetry using the standard 


\section{India}

\section{Telangana}

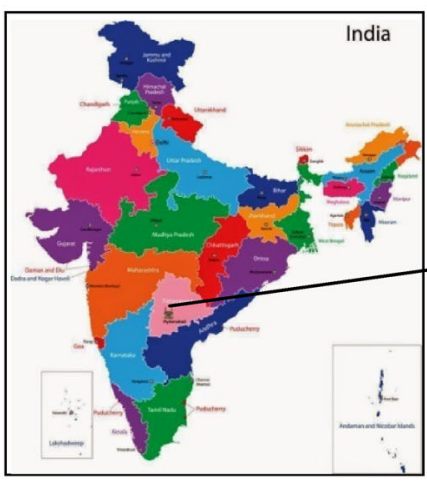

\section{Jawaharnagar}
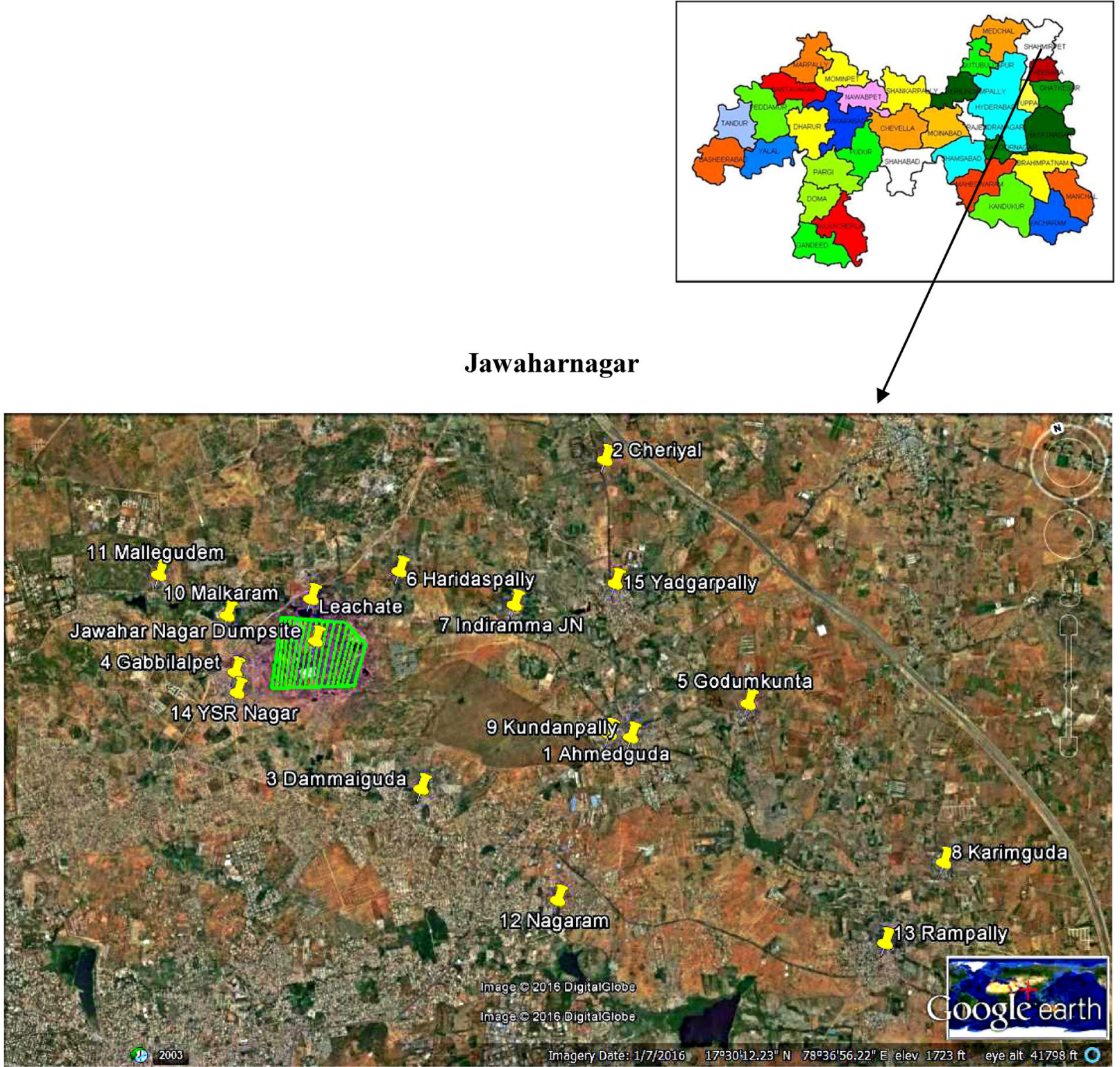

Fig. 3 Location map of study area 


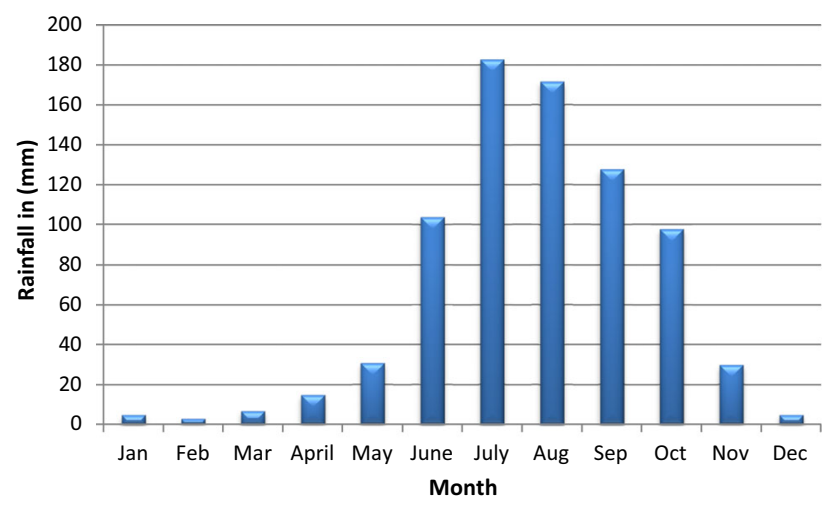

Fig. 4 Monthly rainfall distribution of Ranga reddy District Source: (Ground Water Department, Telangana State (2015)

EDTA. Carbonates and bicarbonates were determined by titration with $\mathrm{H}_{2} \mathrm{SO}_{4}$. Sodium and potassium were determined by flame photometry. Nitrate determination was carried out using Ion-Selective Electrode (Model-Orion4star). Sulphates were measured by Spectrophotometer (Model-Spectronic 21). The analytical data thus obtained could be used for different classifications for various suitability purposes and decision making.

\section{Results and discussion}

\section{Leachate chemistry}

The physico-chemical characteristics of collected leachate around the dumpsite during dry and wet seasons were analyzed and presented in Table 1 . The color of the leachate was dark brownish which can be mainly attributed to the oxidation of ferrous to ferric form and the formation of

Table 1 Physico-chemical characteristics of leachate (dry and wet) seasons

\begin{tabular}{lll}
\hline Parameters & Dry & Wet \\
\hline $\mathrm{pH}$ & 9.6 & 8.2 \\
$\mathrm{EC}$ & 55,000 & 6450 \\
$\mathrm{TDS}$ & 34,775 & 3670 \\
$\mathrm{Ca}^{2+}$ & 12 & 4.8 \\
$\mathrm{Mg}^{2+}$ & 394 & 211 \\
$\mathrm{Na}^{+}$ & 484 & 244 \\
$\mathrm{~K}^{+}$ & 8700 & 2100 \\
$\mathrm{CO}_{3}^{-2}$ & 231 & 195 \\
$\mathrm{HCO}_{3}{ }^{-}$ & 1800 & 812 \\
$\mathrm{NO}_{3}^{-}$ & 460 & 280 \\
$\mathrm{SO}_{4}^{-2}$ & 350 & 122 \\
$\mathrm{Cl}^{-}$ & 45,319 & 12,266 \\
\hline $\mathrm{All}^{-}$ &
\end{tabular}

All parameters are in $\mathrm{mg} / \mathrm{l}$, except $\mathrm{pH}$ and $\mathrm{EC}$ in $\mu \mathrm{S} / \mathrm{cm}$ ferric hydroxide colloids and complexes with fulvic/humic substance (Chu et al. 1994). Leachate $\mathrm{pH}$ is highly alkaline in nature. Alkaline $\mathrm{pH}$ is normally encountered at landfills, 10 years after disposal according to El-Fadel et al. (2002). Other analyzed parameters, such as TDS, TH, $\mathrm{Ca}^{2+}, \mathrm{Mg}^{2+}$, $\mathrm{Na}^{+}, \mathrm{K}^{+}, \mathrm{Cl}^{-}, \mathrm{CO}_{3}{ }^{2-}, \mathrm{HCO}_{3}{ }^{-}, \mathrm{NO}_{3}{ }^{-}$, and $\mathrm{SO}_{4}{ }^{2-}$, were found to have higher concentrations in the leachate collected during dry season when compared to wet season leachate sample which could be due to the dilution process of the contaminating ions. However, the high values of EC $55,000 \mu \mathrm{S} / \mathrm{cm}$ and TDS $34,775 \mathrm{mg} / \mathrm{l}$ recorded during dry season is mainly contributed by the major ions in larger concentrations indicating the presence of inorganic material.

\section{Major ion chemistry of groundwater}

\section{Drinking suitability}

Ground-water samples (No. 15) collected from the study area during dry and wet seasons were analyzed using APHA standards (2005) and compared with the drinking water quality standards (WHO 2011), and statistical information, such as minimum, maximum, mean, and standard deviation, was presented in Tables 2 and 3. The $\mathrm{pH}$ of groundwater ranged from 7.1 to 7.8 and 6.1 to 7.7 during dry and wet seasons, respectively. The $\mathrm{pH}$ results indicate that all the ground-water samples fall within the permissible limits and are in alkaline state according to WHO standards. The EC values of the groundwater ranged from 600 to 2200 and 825 to $2000 \mu \mathrm{S} / \mathrm{cm}$ during dry and wet seasons, respectively. The EC values of all the groundwater samples fall within the permissible levels of WHO standards except for few collected near the dumpsite indicating the impact of leachate on groundwater which may contain more soluble salts. The TDS values of groundwater ranged from 384 to 1408 and 528 to $1280 \mathrm{mg} /$ 1 during dry and wet seasons indicating that almost all the samples exceeded the permissible levels of WHO standards. The calcium $\left(\mathrm{Ca}^{2+}\right)$ values of the groundwater ranged from 65 to 335 and 44 to $300 \mathrm{mg} / \mathrm{l}$ during dry and wet seasons. All the ground-water samples exceeded the permissible levels of WHO standards except for few magnesium $\left(\mathrm{Mg}^{2+}\right)$ values of the groundwater ranged from 27 to 115 and 5 to $92 \mathrm{mg} / \mathrm{l}$. Most of the samples fall within the permissible limits of WHO standards except for few. The highest value of magnesium $(115 \mathrm{mg} / \mathrm{l})$ was recorded in GW15 collected during dry season. The TH values of the groundwater ranged from 200 to 1000 and 199 to $664 \mathrm{mg} / \mathrm{l}$ during dry and wet seasons. All the ground-water samples exceeded the permissible levels of WHO standards. According to Sawyer and McCarthy 1967 classification 
Table 2 Physico-chemical parameters, descriptive statistics of analyzed ground-water samples compared with WHO (2011) (dry)

\begin{tabular}{|c|c|c|c|c|c|c|c|c|c|c|c|c|c|}
\hline S. No & $\mathrm{pH}$ & EC & TDS & $\mathrm{TH}$ & $\mathrm{Ca}^{2+}$ & $\mathrm{Mg}^{2+}$ & $\mathrm{Na}^{+}$ & $\mathrm{K}^{+}$ & $\mathrm{CO}_{3}^{-2}$ & $\mathrm{HCO}_{3}{ }^{-}$ & $\mathrm{NO}_{3}{ }^{-}$ & $\mathrm{SO}_{4}^{-2}$ & $\mathrm{Cl}^{-}$ \\
\hline GW1 & 7.1 & 2200 & 1408 & 590 & 335 & 62 & 129 & 4 & 5 & 190 & 70 & 190 & 859 \\
\hline GW2 & 7.1 & 1000 & 640 & 290 & 175 & 27 & 27 & 4 & 3 & 146 & 162 & 168 & 128 \\
\hline GW3 & 7.1 & 1500 & 960 & 465 & 250 & 52 & 98 & 3 & 6 & 854 & 196 & 124 & 355 \\
\hline GW4 & 7.2 & 800 & 512 & 275 & 110 & 40 & 56 & 3 & 6 & 112 & 165 & 106 & 138 \\
\hline GW5 & 7.3 & 1500 & 960 & 306 & 180 & 29 & 87 & 4 & 12 & 128 & 59 & 173 & 263 \\
\hline GW6 & 7.5 & 1335 & 854 & 410 & 85 & 48 & 116 & 5 & 7 & 160 & 54 & 160 & 1100 \\
\hline GW7 & 7.3 & 1200 & 768 & 250 & 135 & 28 & 95 & 3 & 9 & 152 & 13 & 250 & 340 \\
\hline GW8 & 7.4 & 997 & 876 & 344 & 75 & 38 & 147 & 6 & 6 & 102 & 143 & 112 & 351 \\
\hline GW9 & 7.3 & 1300 & 832 & 465 & 115 & 44 & 142 & 5 & 15 & 85 & 95 & 111 & 319 \\
\hline GW10 & 7.8 & 600 & 384 & 205 & 115 & 28 & 39 & 6 & 6 & 104 & 28 & 110 & 78 \\
\hline GW11 & 7.6 & 1033 & 661 & 311 & 65 & 36 & 95 & 4 & 4 & 117 & 156 & 120 & 206 \\
\hline GW12 & 7.2 & 1200 & 768 & 300 & 135 & 40 & 110 & 4 & 6 & 171 & 73 & 130 & 231 \\
\hline GW13 & 7.5 & 1774 & 991 & 397 & 80 & 48 & 155 & 6 & 7 & 95 & 185 & 160 & 355 \\
\hline GW14 & 7.3 & 1000 & 640 & 1000 & 195 & 73 & 38 & 2 & 0 & 116 & 174 & 187 & 128 \\
\hline GW15 & 7.5 & 700 & 448 & 300 & 115 & 115 & 49 & 3 & 12 & 98 & 49 & 111 & 202 \\
\hline Min & 7.1 & 600 & 384 & 205 & 65 & 27 & 27 & 2 & 0 & 85 & 13 & 106 & 78 \\
\hline Max & 7.8 & 2200 & 1408 & 1000 & 335 & 115 & 155 & 6 & 15 & 854 & 196 & 250 & 1100 \\
\hline Mean & 7.34 & 1209.27 & 780.13 & 393.87 & 144.33 & 47.20 & 92.20 & 4.13 & 6.93 & 175.33 & 108.13 & 147.47 & 336.87 \\
\hline Standard deviation & 0.20 & 418.80 & 255.46 & 194.98 & 73.19 & 22.84 & 42.20 & 1.25 & 3.79 & 190.24 & 62.55 & 41.34 & 280.56 \\
\hline WHO (2011) & $6.5-8.5$ & 1500.00 & 500.00 & 200.00 & 75.00 & 50.00 & 200.00 & 12.00 & NA & NA & 45.00 & 250.00 & 250.00 \\
\hline
\end{tabular}

All parameters are in $\mathrm{mg} / \mathrm{l}$, except $\mathrm{pH}$ and $\mathrm{EC}$ in $\mu \mathrm{S} / \mathrm{cm}$

based on $\mathrm{TH}$, all the ground-water samples in the study area collected during dry and wet seasons fall under hard to very hard category. The $\mathrm{Na}^{+}$values ranged from 27 to 155 and 15 to $110 \mathrm{mg} / \mathrm{l}$ during dry and wet seasons. All the ground-water samples fall within the permissible limits of WHO standards. Potassium values of the groundwater ranged from 2 to 6 and 3 to $10 \mathrm{mg} / \mathrm{l}$ during dry and wet seasons. All the samples fall within permissible limits of WHO standards. The nitrate values of the ground-water samples ranged from 13 to 196 and 19 to $204 \mathrm{mg} / \mathrm{l}$ during dry and wet seasons. All the ground-water samples exceeded the permissible limits of WHO standards except for few. Major sources for nitrate in groundwater include domestic sewage, runoff from agricultural fields, and leachate from landfill sites. Higher concentration of nitrates $(>50 \mathrm{mg} / \mathrm{l})$ in water causes a disease called "Methaemoglobinaemia", also known as "Blue-baby Syndrome'. This disease particularly affects infants that are up to 6-month-old Kapil et al. (2009). The sulphate values of groundwater ranged from 106 to 250 and 49 to $183 \mathrm{mg} / \mathrm{l}$ collected during dry and wet seasons. All the samples of the study area fall within the permissible limits of WHO standards. The chloride values of the groundwater samples ranged from 78 to 1100 and 50 to $998 \mathrm{mg} / \mathrm{l}$ collected during dry and wet seasons. Most of the groundwater samples exceeded the permissible limits of WHO standards except for few. The highest chloride value was recorded in GW6 in both the seasons, which is located at $1.2 \mathrm{~km}$ away from the dumpsite. High concentrations of chlorides are added to the groundwater from the municipal wastes, which clearly indicate the impact of landfill leachate. Other sources include farm drainage and sewage effluents. The abundance of major cations and anions of groundwater collected during dry and wet seasons is as follows: $\mathrm{Ca}^{2+}>\mathrm{Na}^{+}>\mathrm{Mg}^{2+}>\mathrm{K}^{+}>\mathrm{Cl}^{-}>\mathrm{HCO}_{3}^{-}>-$ $\mathrm{SO}_{4}{ }^{2-}>\mathrm{NO}_{3}{ }^{-}>\mathrm{CO}_{3}{ }^{2-}$ and $\mathrm{Ca}^{2+}>\mathrm{Mg}^{2+}>\mathrm{Na}^{+}>-$ $\mathrm{K}^{+}>\mathrm{HCO}_{3}{ }^{-}>\mathrm{Cl}^{-}>\mathrm{NO}_{3}{ }^{-}>\mathrm{SO}_{4}{ }^{2-}>\mathrm{CO}_{3}{ }^{2-}$, respectively.

\section{Hydrochemical facies}

The hydrochemical evolution of groundwater can be understood using the analytical data obtained from groundwater samples as a result of plotting the major cations and anions in the piper trilinear diagram (Piper 1944). The piper diagram consists of three distinct fields: cation ternary field (left), anion ternary field (right), and diamond field (centre). Leachate samples and ground-water samples of both seasons (dry and wet) were plotted on the piper diagram so as to understand their relationship, as it reveals the similarities and differences in the quality. Similar studies were carried out (Syafalni et al. 2014; Akudo et al. 2010; Akpoborie et al. 2015). According to the piper diagrams (Fig. 5a, b; Table 4), the leachate samples 
Table 3 Physico-chemical parameters, descriptive statistics of analyzed ground-water samples compared with WHO (2011) (wet)

\begin{tabular}{|c|c|c|c|c|c|c|c|c|c|c|c|c|c|}
\hline Sl. No & $\mathrm{pH}$ & EC & TDS & $\mathrm{TH}$ & $\mathrm{Ca}^{2+}$ & $\mathrm{Mg}^{2+}$ & $\mathrm{Na}^{+}$ & $\mathrm{K}^{+}$ & $\mathrm{CO}_{3}^{-2}$ & $\mathrm{HCO}_{3}{ }^{-}$ & $\mathrm{NO}_{3}^{-}$ & $\mathrm{SO}_{4}^{-2}$ & $\mathrm{Cl}^{-}$ \\
\hline GW1 & 6.8 & 1078 & 690 & 664 & 200 & 40 & 110 & 3 & 5 & 205 & 64 & 155 & 827 \\
\hline GW2 & 7.4 & 825 & 528 & 335 & 76 & 35 & 35 & 3 & 636 & 659 & 180 & 114 & 294 \\
\hline GW3 & 6.8 & 2000 & 1280 & 365 & 100 & 28 & 25 & 5 & 546 & 384 & 168 & 135 & 344 \\
\hline GW4 & 7.1 & 1300 & 832 & 250 & 90 & 6 & 18 & 10 & 0 & 1208 & 204 & 51 & 266 \\
\hline GW5 & 7.7 & 1450 & 928 & 400 & 56 & 63 & 28 & 4 & 0 & 1311 & 40 & 56 & 355 \\
\hline GW6 & 7.5 & 1058 & 677 & 434 & 89 & 53 & 43 & 5 & 7 & 172 & 25 & 146 & 998 \\
\hline GW7 & 6.7 & 909 & 582 & 408 & 100 & 20 & 54 & 5 & 6 & 70 & 35 & 86 & 295 \\
\hline GW8 & 7.3 & 965 & 618 & 388 & 78 & 47 & 68 & 4 & 8 & 250 & 100 & 131 & 340 \\
\hline GW9 & 7.4 & 1050 & 672 & 323 & 70 & 36 & 27 & 8 & 180 & 659 & 111 & 65 & 355 \\
\hline GW10 & 7.5 & 950 & 608 & 225 & 140 & 21 & 15 & 9 & 6 & 920 & 19 & 49 & 121 \\
\hline GW11 & 7.1 & 826 & 529 & 348 & 70 & 42 & 29 & 3 & 7 & 125 & 128 & 138 & 196 \\
\hline GW12 & 7.3 & 1500 & 960 & 285 & 44 & 46 & 25 & 4 & 0 & 1495 & 77 & 117 & 223 \\
\hline GW13 & 7.3 & 1095 & 701 & 517 & 105 & 62 & 75 & 5 & 5 & 245 & 167 & 183 & 333 \\
\hline GW14 & 7.2 & 900 & 576 & 199 & 60 & 12 & 16 & 4 & 66 & 61 & 142 & 50 & 202 \\
\hline GW15 & 7 & 1050 & 672 & 285 & 92 & 92 & 23 & 8 & 0 & 1385 & 150 & 115 & 50 \\
\hline Min & 6.7 & 825 & 528 & 199 & 44 & 6 & 15 & 3 & 0 & 61 & 19 & 49 & 50 \\
\hline Max & 7.7 & 2000 & 1280 & 664 & 200 & 92 & 110 & 10 & 636 & 1495 & 204 & 183 & 998 \\
\hline Mean & 7.21 & 1130.4 & 723.53 & 361.73 & 91.33 & 40.2 & 39.4 & 5.33 & 98.13 & 609.93 & 107.33 & 106.07 & 346.6 \\
\hline Standard deviation & 0.29 & 315.53 & 201.89 & 38.09 & 38.09 & 22.14 & 26.71 & 2.29 & 206.19 & 523.16 & 61.25 & 43.65 & 248.59 \\
\hline WHO (2011) & $6.5-8.5$ & 1500.00 & 500.00 & 200.00 & 75.00 & 50.00 & 200.00 & 12.00 & NA & NA & 45.00 & 250.00 & 250.00 \\
\hline
\end{tabular}

All parameters are expressed in $\mathrm{mg} / \mathrm{l}$, except $\mathrm{pH}$ and $\mathrm{EC}$ in $\mu \mathrm{S} / \mathrm{cm}$

collected during dry and wet seasons fall in $\mathrm{Na}^{+} / \mathrm{K}^{+}$and $\mathrm{Cl}^{-}$class type which can be observed from anion and cation ternary fields. The majority of the ground-water samples fall in $\mathrm{Cl}^{-}$class type along with leachate both in dry and wet seasons which can be observed from the anion ternary field and are a clear indication of leachate pollution. According to Panno et al. (2006); Uma (2004); Hanchar (1991); Baedecker and Back (1979), dumpsite, landfill leachate, and sewage are indeed known sources of chloride, bicarbonate, calcium, and magnesium loading to native groundwater. From the plot, alkaline earth $\left(\mathrm{Ca}^{2+}\right.$ and $\mathrm{Mg}^{2+}$ ) exceed alkalies $\left(\mathrm{Na}^{+}\right.$and $\left.\mathrm{K}^{+}\right)$, while the strong acids $\left(\mathrm{Cl}^{-}\right.$and $\left.\mathrm{SO}_{4}{ }^{2-}\right)$ exceed the weak acids $\left(\mathrm{CO}_{3}{ }^{2-}\right.$ and $\mathrm{HCO}_{3}{ }^{-}$). Therefore, the dominant ground-water type of the study area can be observed as $\mathrm{CaCl}_{2}$ type.

\section{Irrigation suitability}

The suitability assessment of groundwater for irrigation purpose is essential to provide good quality water for a proper growth of crop plants. The classification systems used to evaluate the suitability of groundwater for irrigation purpose can be determined through the indices, such as percentage sodium $(\mathrm{Na} \%)$, sodium adsorption ratio (SAR), Kelley's ratio (KR), and permeability index (PI), sodium soluble percentage (SSP) and USSL classification.

\section{Salinity}

Electrical conductivity (EC) is a measure of the dissolved ionic salts present in the groundwater. EC is a good measure of salinity hazard to crops, as it reflects the TDS in groundwater (Subramani et al. 2005). During dry season, $80 \%$ of the ground-water samples fall under "permissible" category, $13 \%$ fall under "good" category, and $7 \%$ fall in "doubtful" category for irrigation purpose. During wet season, $100 \%$ of ground-water samples fall in "permissible" category for irrigation purpose (Table 5). Excessive high salinity can affect the plants causing specific toxicity of sodium and higher osmotic pressure around the roots, thus preventing an efficient water absorption by the plants.

According to Wilcox (1955), in all natural waters, $\mathrm{Na} \%$ is a common parameter to assess its suitability for irrigational purposes. The sodium in irrigation water in usually denoted as \% $\mathrm{Na}$ and can be determined using the formula:

$\% \mathrm{Na}=\frac{\left(\mathrm{Na}^{+}\right) \times 100}{\left(\mathrm{Ca}^{2+}+\mathrm{Mg}^{2+}+\mathrm{Na}^{+}+\mathrm{K}^{+}\right)}$.

From Table 6, it can be observed that the ground-water samples of the study area collected during dry and wet seasons fall under "excellent" to "permissible" limits for irrigation. 
(a)

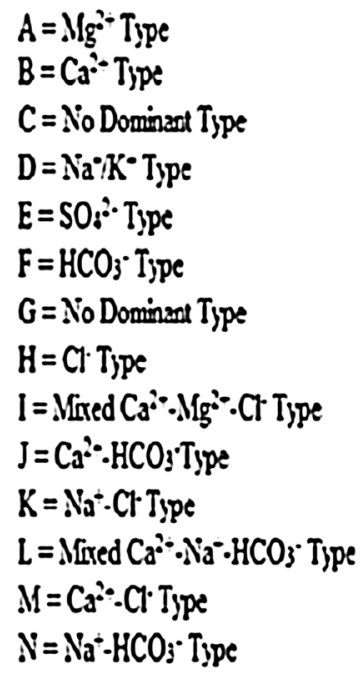

$A=N g+$ Type
$B=C+T p e$

$C=$ No Dominast Tspe

$D=N_{a} * K^{*}$ Type

$\mathrm{E}=\mathrm{SO}^{\prime} \cdot \mathrm{T}$. $\mathrm{ppe}$

$\mathrm{F}=\mathrm{HCO}_{3} \cdot \mathrm{T}$ jpe

$G=$ No Dominast Type

$\mathrm{H}=\mathrm{Cl} \cdot \mathrm{T}_{\text {jpe }}$

$\mathrm{I}=\mathrm{Mrred} \mathrm{Ca}^{\circ} \cdot \mathrm{A} \mathrm{Ig}_{\mathrm{g}} \cdot \mathrm{Cr}$ Type

$\mathrm{J}=\mathrm{Ca}^{2} \cdot \mathrm{HCO}_{3}$ Tspe

$\mathrm{K}=\mathrm{Na}^{\top} \cdot \mathrm{Cr}$ Type

$\mathrm{L}=\mathrm{Sirred} \mathrm{Ca}^{\circ} \cdot 0 \mathrm{Na}^{-} \cdot \mathrm{HCO}_{3} \cdot$ Type

$\mathrm{N}=\mathrm{Na} \cdot \mathrm{HCO}^{-} \cdot \mathrm{Tppe}$

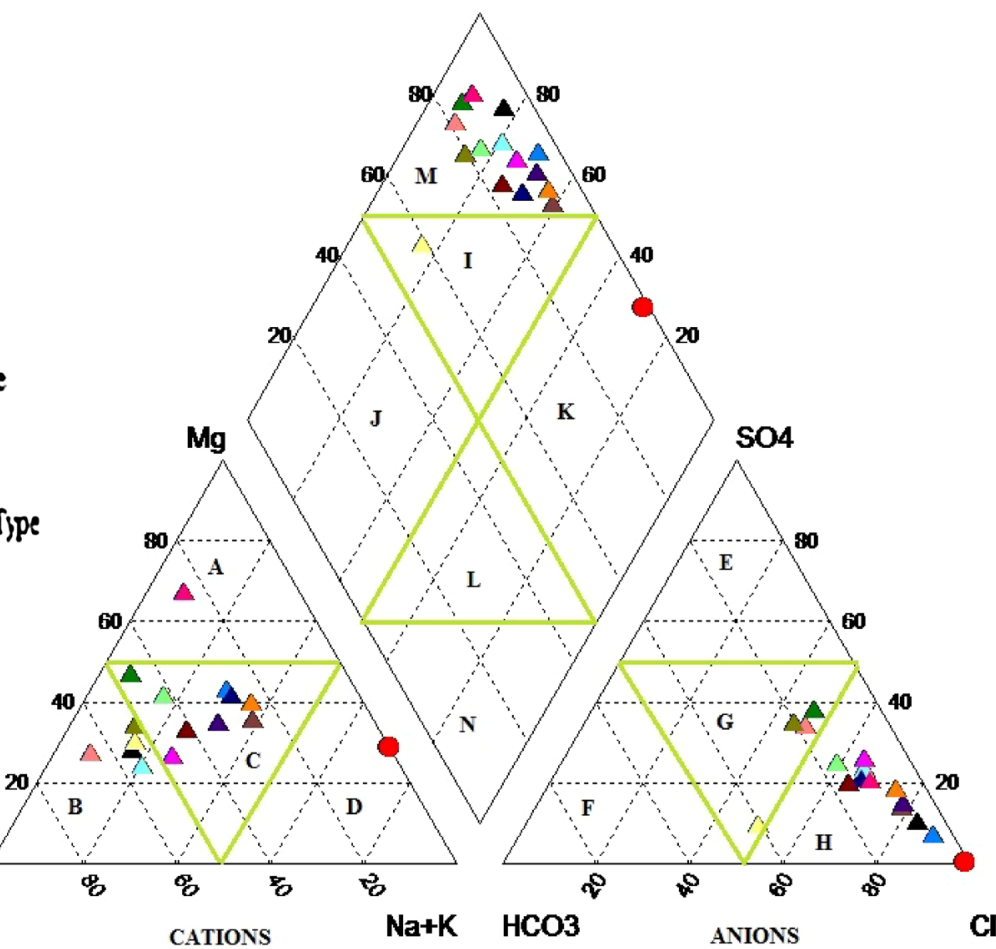

\begin{tabular}{|l||}
\hline Legend \\
$\Delta$ Ahmedguda \\
Dammaiguda \\
Aabbilalpet \\
A Godumkunta \\
A Haridaspally \\
Andiramma Jinnaram \\
A Karimguda \\
A Kundanpally \\
- Leachate \\
A Malkaram \\
A Mallegudem \\
A Nagaram \\
A Rampally \\
A Y.S.R nagar \\
A Yadgarpally \\
\hline
\end{tabular}

$\mathrm{Ca}$

CATIONS

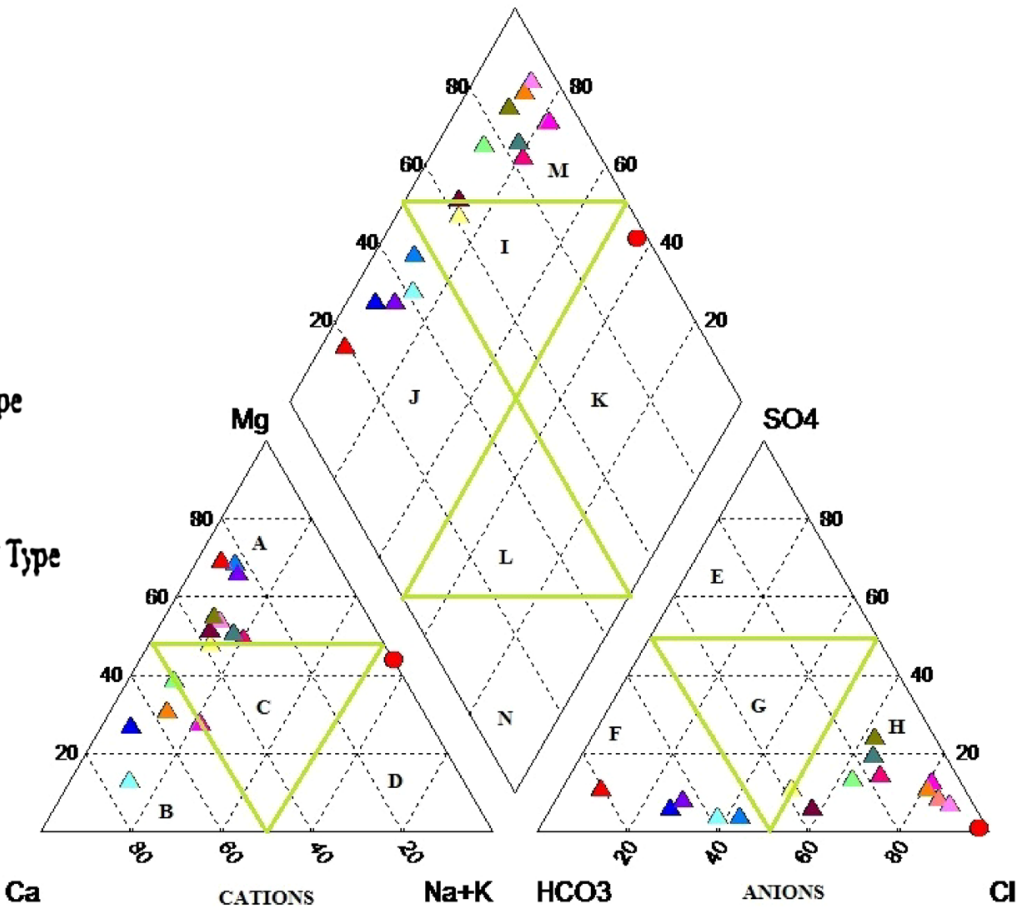

Legend

$\triangle$ Ahmedguda

Cheriyal

Dammaiguda

Gabbilalpet

A Godumkunta

$\triangle$ Haridaspally

A Indiramma Jinnaram

A Karimguda

A Kundanpally

- Leachate

A Malkaram

A Mallegudem

A Nagaram

$\triangle$ Rampally

A Y.S.R Nagar

$\Delta$ Yadgarpally

Fig. 5 a Piper diagram of Leachate and groundwater of the study area (dry). b Piper diagram of leachate and groundwater of the study area (wet) 
Table 4 Ground-water type based on piper diagram for Jawaharnagar dumpsite

\begin{tabular}{|c|c|c|c|}
\hline & Dry & Wet & Class type \\
\hline \multicolumn{4}{|c|}{ Cation ternary field } \\
\hline \multirow[t]{3}{*}{ Groundwater } & 1 & 9 & (A) Magnesium $\left(\mathrm{Mg}^{2+}\right)$ type \\
\hline & 5 & 5 & (B) Calcium $\left(\mathrm{Ca}^{2+}\right)$ type \\
\hline & 9 & - & (C) No dominant type \\
\hline Leachate & Leachate (dry) & Leachate (wet) & (D) $\mathrm{Na}^{+} / \mathrm{K}^{+}$type \\
\hline \multicolumn{4}{|c|}{ Anion ternary field } \\
\hline \multirow[t]{3}{*}{ Groundwater } & 4 & 1 & (E) No dominant type \\
\hline & 0 & 5 & (F) Bicarbonate $\left(\mathrm{HCO}_{3}^{-}\right)$type \\
\hline & 11 & 10 & (G) Chloride $\left(\mathrm{Cl}^{-}\right)$type \\
\hline Leachate & Leachate (dry) & Leachate (wet) & (H) Chloride $\left(\mathrm{Cl}^{-}\right)$type \\
\hline \multicolumn{4}{|c|}{ Central diamond field } \\
\hline \multirow[t]{3}{*}{ Groundwater } & 1 & 1 & (I) Mixed $\mathrm{Ca}^{2+}-\mathrm{Mg}^{2+}-\mathrm{Cl}^{-}$type \\
\hline & 0 & 5 & (J) $\mathrm{Ca}^{2+}-\mathrm{HCO}_{3}{ }^{-}$type \\
\hline & 14 & 8 & (K) $\mathrm{Ca}^{2+}-\mathrm{Cl}^{-}$type \\
\hline Leachate & Leachate (dry) & Leachate (wet) & (L) $\mathrm{Na}^{+} \mathrm{Cl}^{-}$Type \\
\hline
\end{tabular}

Table 5 Irrigation water quality based on EC values

\begin{tabular}{llll}
\hline Water class & EC values & \multicolumn{2}{c}{$\%$ compliance } \\
\cline { 3 - 4 } & & Dry & Wet \\
\hline Excellent & $<250$ & - & - \\
Good & $250-750$ & $13 \%$ & - \\
Permissible & $750-2000$ & $80 \%$ & $100 \%$ \\
Doubtful & $2000-3000$ & $7 \%$ & - \\
Unsuitable & $>3000$ & - & - \\
\hline
\end{tabular}

Table 6 Irrigation water quality based on $\% \mathrm{Na}$

\begin{tabular}{llll}
\hline Water class & $\% \mathrm{Na}$ & \multicolumn{2}{c}{$\%$ compliance } \\
\cline { 3 - 4 } & & Dry & Wet \\
\hline Excellent & $<20$ & $26 \%$ & $73 \%$ \\
Good & $20-40$ & $67 \%$ & $20 \%$ \\
Permissible & $40-60$ & $7 \%$ & $7 \%$ \\
Doubtful & $60-80$ & - & - \\
Unsuitable & $>80$ & - & - \\
\hline
\end{tabular}

\section{Sodium adsorption ratio (SAR)}

The SAR is the most useful parameter for determining the suitability of groundwater for irrigation purposes, because it measures the alkali/sodium hazard to crops (Subrahmanyam and Yadaiah 2000). It can be determined using the following formula introduced by Karanth (1987) (Table 7):

$\mathrm{SAR}=\frac{\mathrm{Na}^{+}}{\sqrt{\left(\mathrm{Ca}^{2+}+\mathrm{Mg}^{2+}\right) / 2}}$

where sodium, calcium, and magnesium are in meq/L.The results of the SAR values indicated that all the ground-water
Table 7 Irrigation water quality based on SAR (after Karanth 1987)

\begin{tabular}{llll}
\hline Water class & SAR values & \multicolumn{2}{l}{$\%$ compliance } \\
\cline { 3 - 4 } & & Dry & Wet \\
\hline Excellent & $<10$ & $100 \%$ & $100 \%$ \\
Good & $10-18$ & - & - \\
Doubtful & $18-26$ & - & - \\
Unsuitable & $>26$ & - & - \\
\hline
\end{tabular}

samples of the study area collected during dry and wet seasons fall in "excellent" category for irrigation. US Salinity diagram was also used to determine irrigation water suitability by plotting SAR against EC. The USSL (1954) plot indicated that $86 \%$ of the ground-water samples collected during dry season fall in C3S1 field, which indicates high salinity and low-sodium type and $14 \%$ of the samples fall in C2S1 field which indicates medium salinity and low-sodium type, whereas $100 \%$ of the samples collected during wet season fall in $\mathrm{C} 3 \mathrm{~S} 1$ category indicating high salinity and low-sodium type (Fig. 6a, b). High salinity water can be used only on the soils with adequate drainage and salt tolerant plants must be selected. Low-sodium-type water can be used for irrigation purpose on almost all the types of soils with little danger of exchangeable sodium (Hem 1989).

\section{Sodium Soluble Percentage (SSP)}

It is also to evaluate the sodium hazard. The SSP is calculated as follows (Todd 1995):

$\mathrm{SSP}=\frac{\left(\mathrm{Na}^{+}+\mathrm{K}^{+}\right) \times 100}{\left(\mathrm{Na}^{+}+\mathrm{K}^{+}+\mathrm{Ca}^{2+}+\mathrm{Mg}^{2+}\right)}$.

All ions are expressed in meq/L. Based on the calculated values (Table 8), all the ground-water samples of the study 
Fig. 6 a USSL classification of groundwater of the study area (dry). b USSL classification of groundwater of the study area (wet)
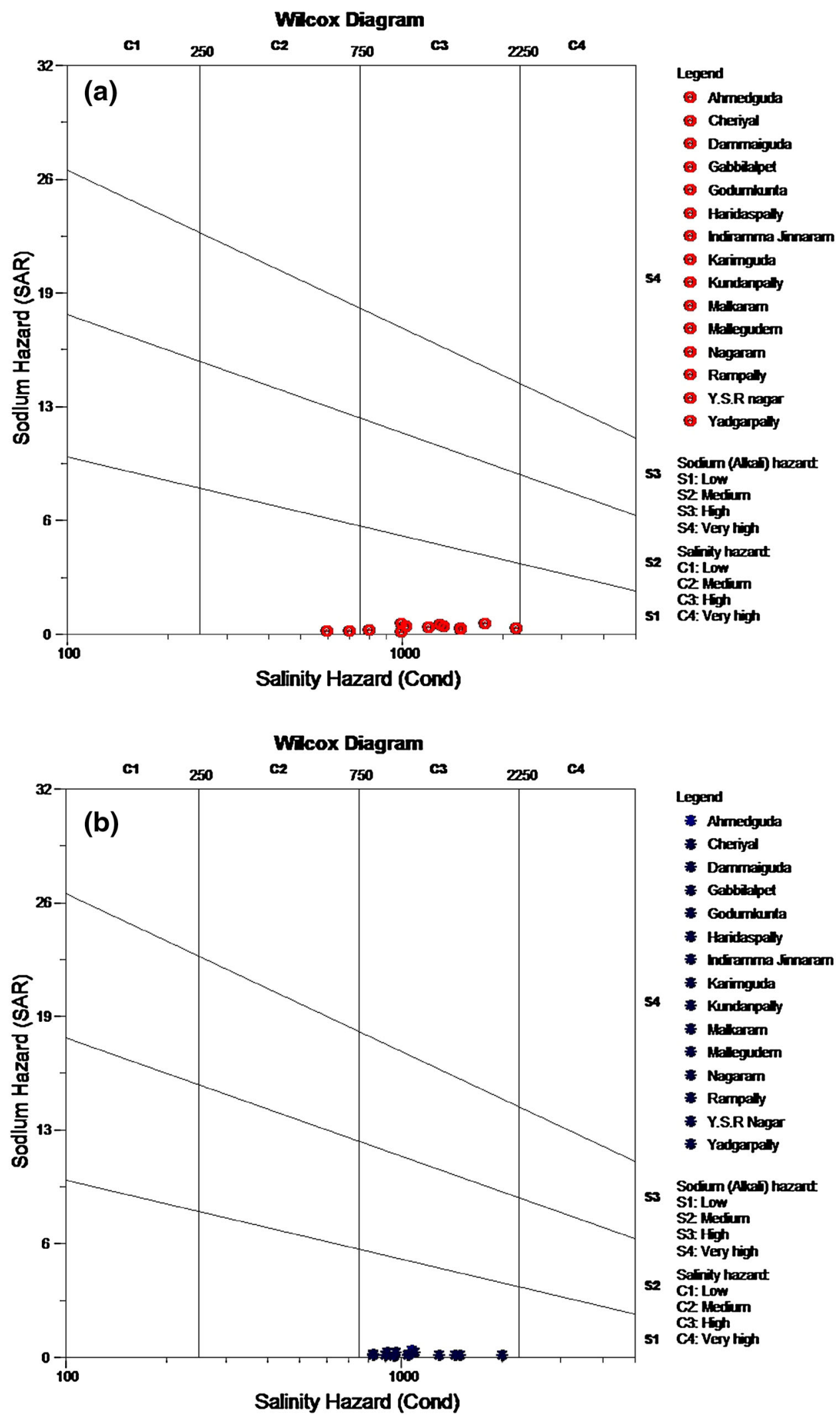
Table 8 Irrigation water quality based on SSP (after Todd 1995)

\begin{tabular}{llll}
\hline Water class & SSP values & \multicolumn{2}{l}{$\%$ compliance } \\
\cline { 3 - 4 } & & Dry & Wet \\
\hline Excellent & $<60$ & $100 \%$ & $100 \%$ \\
Good to permissible & $60-75$ & - & - \\
Doubtful to unsuitable & $>75$ & - & - \\
\hline
\end{tabular}

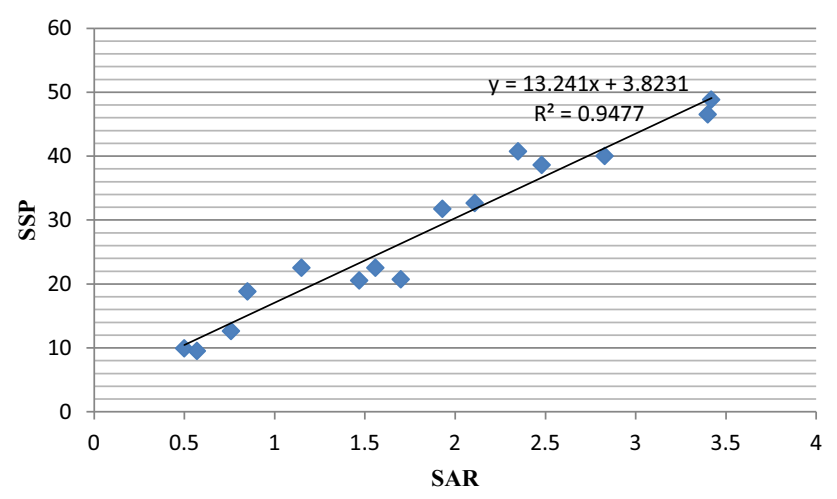

Fig. 7 SAR vs SSP for irrigation water

Table 9 Irrigation water quality based on KR (after Kelly 1963)

\begin{tabular}{llll}
\hline Water class & KR values & \multicolumn{2}{l}{$\%$ compliance } \\
\cline { 3 - 4 } & & Dry & Wet \\
\hline Good & $<1$ or 1 & $100 \%$ & $100 \%$ \\
Unsuitable & $>1$ & - & - \\
\hline
\end{tabular}

area fall in "excellent" class suitable for irrigation. Positive correlation between SAR and $\operatorname{SSP}\left(R^{2}=0.9477\right)$ is shown in Fig. 7.

\section{Kelley's Ratio (KR)}

The KR values are calculated by the formula given by Kelly (1963):

$\mathrm{KR}=\frac{\left(\mathrm{Na}^{+}\right)}{\left(\mathrm{Ca}^{2+}+\mathrm{Mg}^{2+}\right)}$.

KR values of 1 or $<1$ indicate suitability, while KR values of $>1$ indicate unsuitability for irrigation purpose. Based on this classification, all the ground-water samples collected during dry and wet seasons fall in "good" category for irrigation purpose, i.e., below ( $<1$ or 1) (Table 9).

\section{Permeability Index (PI)}

The PI values also indicate the suitability of groundwater for irrigation. This index is used to evaluate the effects of water quality on the physical properties of the soil. It is
Table 10 Irrigation water quality based on PI (after Doneens 1964)

\begin{tabular}{llll}
\hline Water class & PI values & \multicolumn{2}{l}{$\%$ compliance } \\
\cline { 3 - 4 } & & Dry & Wet \\
\hline Excellent & $>75$ & - & $13 \%$ \\
Good to permissible & $75-25$ & $80 \%$ & $87 \%$ \\
Doubtful to unsuitable & $<25$ & $20 \%$ & - \\
\hline
\end{tabular}

calculated by the following equation which was developed by Doneen (1964):

$\mathrm{PI}=\frac{\left(\mathrm{Na}^{+}+\sqrt{\mathrm{HCO}_{3}^{-}}\right) \times 100}{\left(\mathrm{Ca}^{2+}+\mathrm{Mg}^{2+}+\mathrm{Na}^{+}\right)}$,

where all ions are expressed in meq/L. During dry season, the majority of the samples $(80 \%)$ fall in "good to permissible" category and $20 \%$ of the samples fall in "doubtful to unsuitable" category. During wet season, most of the samples $(87 \%)$ fall in "good to permissible" and $13 \%$ of the samples fall in "excellent" category for irrigation purpose (Table 10).

\section{Conclusion}

The leachate characteristics studied reveal that almost all the parameters carried out were found to have higher concentrations during dry season with slight dilutions in wet season. The interpretations of the hydrochemical analyses of the groundwater collected in both the seasons reveal the unsuitability for drinking purpose considering drinking water quality standards. Hydrochemical facies studies reveal that most of the ground-water samples fall in the $\mathrm{Cl}$ type along with the leachate which can be witnessed from piper diagram plotted for both the seasons. It can be observed that the groundwater having higher concentrations of $\mathrm{Ca}^{+2}, \mathrm{Cl}^{-}$, and $\mathrm{NO}_{3}{ }^{-}$can be used as an indication of leachate percolation into the groundwater which can have deleterious effects to humans if consumed. According to the irrigation water quality classification limits, most of the ground-water samples of the study area are suitable for various irrigation needs. However, salt tolerant plants/crops are appropriate, as the water is highly saline in nature which can be witnessed from the USSL diagram. Finally, it can be concluded that leachate emanating from the dumpsite is causing an environmental risk which has to curb immediately, as it is highly dangerous in every aspect of the life.

Acknowledgments I am extremely thankful to Dr. Ramana Kumar (Lab Incharge) for assisting me and UGC-RGNF (University Grant Commission-Rajiv Gandhi National Fellowship) for providing financial assistance to carry out my work. 
Open Access This article is distributed under the terms of the Creative Commons Attribution 4.0 International License (http:// creativecommons.org/licenses/by/4.0/), which permits unrestricted use, distribution, and reproduction in any medium, provided you give appropriate credit to the original author(s) and the source, provide a link to the Creative Commons license, and indicate if changes were made.

\section{References}

Akpoborie IA, Aweto KE, Ohwoghene-Asuma O (2015) Urbanization and major ion hydrogeochemistry of the shallow aquifer at the Effurun-Warri Metropolis, Nigeria. Environ Poll 4(1). doi:10. 5539/ep.v4n1p37. ISSN:1927-0917

Akudo Ernest Orji, Ozulu George Uchebike, Osogbue Lewis Chucks (2010) Quality assessment of groundwater in selected waste dump site areas in Warri. Environ Res J 4(4):281-285

American Public Health Association (2005) Standard method for the examination of water and waste water (21st edn). Washington, DC:APHA-AWWA-WEF

Baedecker M, Back W (1979) Hydrogeological processes and chemical reactions at a landfill. Groundwater 17(5):429-437

Chu LM, Cheung KC, Wong MH (1994) Variations in the chemical properties of landfill leachate. Environ Manag 18:105-117

Doneen LD (1964) Notes on water quality in agriculture. Published as a water science and engineering paper 4001, Dept. of Water Science and Engineering, University of California

El-Fadel M, Bou-Zeid E, Chahine W, Alayli B (2002) Temporal variation of leachate quality from pre-sorted and baled municipal solid waste with high organic and moisture content. Waste Manag (Oxford) 22:269-282

Fatta D, Papadopoulos A, Hoizidoi MA (1999) A study on the landfill leachate and its impact on the ground water quality on the greater area. Environ Geochem Health 21:175-190

Gowtham Raj G, Joseph P, Harsha BLS, Ravi Varma K, Sarath Chandra Y (2015) Solid Waste management scenario in India, Issues in MSW and case study of Jawaharnagar, Hyderabad and Bengaluru Planning Colloquium. http://www.slideshare.net/ kamsaniravivarma/msw-in-india

Hanchar DW (1991) Effects of septic-tank effluent on ground-water quality in northern Williamson County and southern Davidson County, Tennessee U. S. Geological Survey Water-Resources Investigations Report, 91-4011

Hem JD (1989) Study and interpretation of the chemical characteristics of natural water, 3rd edition. United States Geological Survey Water Supply Paper 2254. U.S. Geological Survey, Alexandria, Virginia, USA, p 263

Jhamnani B, Singh SK (2009) Ground water contamination due to Bhalaswa landfill site in New Delhi. Int J Civil Environ Eng $1: 121-125$
Kapil DM, Kumari M, Sharma DK (2009) Hydrochemical analysis of drinking water quality of Alwar District Rajasthan. Nat Sci $7(2): 30-39$

Karanth KR (1987) Groundwater assessment, development and management, vol 720. Tata Mc Graw Hill, New Delhi, p 197

Kelly WP (1963) Use of saline irrigation water. Soil Sci 95:355-391

Longe EO, Balogun MR (2010) Ground water quality assessment near a municipal landfill, Lagos, Nigeria. Res J Appl Sci Eng Technol 2:39-44

Panno SV, Hackley KC, Hwang HH, Greenberg SE, Krapac IG, Landsberger S, Kelly DJ (2006) Characterization and identification of the sources of $\mathrm{Na}-\mathrm{Cl}$ in ground water. Ground Water 44(2):176-187

Piper AM (1944) A graphical procedure in the geochemical interpretation of water. Trans Am Geophys Union 25:914-928

Sabahi EA, Rahim Abdul, Wan Zuhairi WY, Nozaily Fadhl Al, Alshaebi Fares (2009) The characteristics of leachate and Ground water pollution at municipal waste solid landfill of Ibb city, Yemen. Am J Environ Sci 5:256-266

Sawyer GN, McCarthy DL (1967) Chemistry of sanitary engineers, 2nd edn. Mc Graw Hill, New York, p 51

Soujanya KB (2016) Characterization of Leachate and its effects on ground water quality around Jawaharnagar Municipal open dumpsite, Rangareddy, Telangana. Curr World Environ 11(1). doi:10.12944/CWE.11.1.15

Subrahmanyam K, Yadaiah P (2000) Assessment of the impact of industrial effluents on water quality in Patancheru and environs, Medak district, Andhra Pradesh, India. Hydrogeol J 9(3):297-312

Subramani T, Elango L, Damodarasamy SR (2005) Groundwater quality and its suitability for drinking and agricultural use in Chithar River Basin, Tamil Nadu, India. Environ Geol 47:1099-1110

Syafalni S, Zawawi MH, Abustan I (2014) Isotopic and hydrochemistry fingerprinting of leachate migration in shallow groundwater at controlled and uncontrolled landfill sites. World Appl Sci J 31(6):1198-1206

Todd DK (1995) Groundwater hydrology, 3rd edn. Wiley, New York

Uma KO (2004) Hydrogeology of the perched aquifer systems in the hilly terrains of Nsukka Town, Enugu State, Nigeria. Water Resour 14:85-92

USSL (1954) Diagnosis and improvement of saline and alkali soil. USDA, Hand Book no. 60, Washington

Vasanthi P, Kaliappan S, Srinivasaraghavan R (2008) Impact of poor solid waste management of ground water. Environ Monit Assess 143:227-238

WHO (2011) Guidelines for drinking-water quality, 4th edn. Geneva 27, Switzerland

Wilcox LV (1955) Classification and use of irrigation water, USDA, Circular No. 969, Washington, DC, p 19 